\title{
IMMUNE RESPONSE OF HORSES VACCINATED WITH TISSUE CULTURE INACTIVATED EHV-1 OIL (MONTANIDE ISA-70) ADJUVANTED VACCINE
}

\author{
WARDA, SAFAA A. and G.M.HUSSIEN
}

Veterinary Serum \& Vaccine Research Institute, Abbasia, Cairo.

(Manuscript received 12 April 2012)

\begin{abstract}
Tissue culture inactivated ISA-70 oil adjuvanted EHV-1 vaccine was successfully prepared from the local isolate. The virus was completely inactivated by $0.008 \mathrm{M}$ of binary ethyleneimine (BEI) within 24 hours at $37^{\circ} \mathrm{C}$. Mineral oil (ISA-70) achieves long term immunity \& good seringeabilty. The vaccine proved to be safe, immunogenic in the inoculated mice $\&$ pregnant mares. It was potent in vaccinated horses with protective level of neutralizing \& complements fixing and AGPT antibodies for 5 months. The duration of virus recovery in vaccinated mice after challenge was 4 days compared with 9 days in the control group. The stability of the prepared vaccine was studied whereas it could be stored at $4^{\circ} \mathrm{C}$, and withstand room temperature and $37^{\circ} \mathrm{C}$ for 2 years.
\end{abstract}

\section{INTRODUCTION}

Equine herpesvirus-1(EHV-1) in particular, is capable of progression beyond the respiratory mucosa to cause the more serious disease manifestations of abortion, perinatal foal death, or neurological dysfunction.( OIE ,2008).

Since the main role of controlling this disease is still by vaccination thus, firstly EHV-1 inactivated vaccine was prepared from aborted foal or from infected hamsters (Doll \& Bryans 1963) which induced undesirable local or systemic adverse reaction with poor protection against challenge. Tissue culture vaccine was used either on 10-14 passages of porcine kidney (Mayr et. al., 1978) or equine foetal dermis which called pneumabort. It was immunogenic and safe in pregnant mares stimulating higher level of virus neutralizing antibodies and cell mediated immune responses. Also it reduced the virus shedding and the clinical signs following challenge (Bryans, 1978). Thomson et.al. (1978) used equine foetal kidney in preparation of partially purified, ultracentrifuged inactivated virus with different adjuvants, that was immunogenic in horses. EHV-1 \& EHV-4 formalin inactivated vaccine with carbomer adjuvant (Durvaxyn) was produced by Yoland Bishop, (2001).

Patel et.al, (2003) prepared a vaccine on mouse fibroblast \& equine dermal cells which produced partial protection but reduced the viral clearance. Inactivated EHV-1 vaccine was recommended to be used at $5^{\text {th }}, 7^{\text {th }} \& 9^{\text {th }}$ month of pregnancy 
(Shinner \& Davis 2000), therefore, the present study was designated to prepare a tissue culture inactivated EHV-1 vaccine from locally isolated strain adjuvanted with stable, good seringeability, safe and immunogenic oil (Montanide ISA-70 ) and assessment its potency in both mice and horses.

\section{MATERIALS AND METHODS}

\section{I- Virus}

Freeze dried EHV-1 of locally isolated virus (Hassanein et al. , 2002 ,) was used.

\section{Antisera}

A) Freeze dried rabbit anti EHV-1 Serum was kindly supplied by Dr. Jennet wellington, Research follow , Dept. of biological science, Maquairia , Univ , NSW , Australia it was used for virus identity.

B) Rabbit anti EHV-1 hyper immune serum prepared locally and used as a positive serum control in serological test.

\section{Animals}

Eight apparently healthy adult mares and 70 mice, 4-6 weeks old were used to evaluate the potency, safety and the stability of the prepared vaccine.

\section{African green monkey kidney cells (VERO)}

It was maintained and grow in Eagle's minimum essential media supplemented with $10 \%$ newly born calf serum and penicillin sodium $100 \mathrm{IU} / \mathrm{ml}$ with strepto-mycin 100 $\mathrm{mg} / \mathrm{ml}$.

\section{Embryonated chicken eggs (ECE)}

Specific pathogen free (SPF) ECE (11-13 days old) were used for assurance of complete virus inactivation.

\section{Binary ethyleneimine (BEI)}

$0.01 \mathrm{M}$ and $0.008 \mathrm{M}$ binary ethyleneimine (Aldrich chemical Co. LTD) were used as virus inactivator according to Bahnemann (1997).

\section{Mineral oil ISA-70}

Montanide ISA-70 contains a new immunostimulants listed as GRAS substance. It achieves rapid, long term protective immune response (single dose /year) and of good seringeability .IT was sterilized by autoclaving.

\section{Preparation of vaccine virus fluid}

Locally isolated seed virus of EHV-1 was propagated on VERO cells, titrated and calculated according to the method of Reed \& Muench (1938). 


\section{IX- Identity test}

It was carried out by SNT using reference anti EHV-1 serum and PCR (OIE, 2008).

\section{$\mathbf{X}$-Virus inactivation}

The prepared viral fluid was inactivated by BEI in two concentrations of $0.008 \mathrm{M}$ and $0.01 \mathrm{M}$ separately (Nehal, 2006). The control virus and the inactivated one were incubated at $37^{\circ} \mathrm{C}$ for 24 hours with continous stirring followed by immediate addition of sterile solution of sodium thiosulphate at final concentration $2 \%$ to stop the action of BEI on the virus and neutralize the toxic action of residual inactivator on target host (Hassanein,1992). Samples were taken at different intervals of time to determine the suitable time of virus inactivation.

\section{XI- Residual infective virus activity}

It was applied by inoculation of inactivated virus fluid either on:-

1. Chorioallantoic membrane (CAM) of embryonated chicken eggs (ECE) 11-13days then incubated at $37^{\circ} \mathrm{C}$ for five days with daily examination to ensure freedom of any residual virus, pock lesion should not be detected in the inoculated eggs(OIE,2008)

2. VERO cells which was incubated at $37^{\circ} \mathrm{C}$ for seven days with daily observation for the presence of $\mathrm{CPE}$, blind passage was done to ensure complete virus inactivation,

\section{XII- Vaccine preparation}

The inactivated virus fluid and Montanide oil (ISA -70) was mixed (W/W) forming stable water in oil emulsion (W/O).

\section{XIII- Vaccine quality control}

1. Sterility test.

Samples from the final vaccine product were tested for bacterial, fungal \& mycoplasma contamination (OIE, 2008)

2. Safety test

a- In susceptible host, it was performed according to OIE, 2008.

Four pregnant mares (at last third of pregnancy) were used, two mares were inoculated I/M with $2 \mathrm{ml}$ of the prepared vaccine. Another two mares kept under observation in a good hygienic condition for two weeks as control.

b- In pregnant mice, the test was conducted in two groups of pregnant mice. The first group was inoculated intranasally (I/N) with $45 \mu$ of inactivated virus and the second group, inoculated subcutaneously $(\mathrm{S} / \mathrm{C})$ with $0.2 \mathrm{ml}$ of the prepared vaccine (Kirisawa et. al., 1995). 


\section{Immunogenicity of tissue culture inactivated oil adjuvant EHV -1 vaccine}

\section{1- In mice :}

Two groups of mice 4-6 weeks old (28 mouse/group) was used for testing the potency of the prepared vaccine - Group (A) was inoculated S/C with $0.2 \mathrm{ml} /$ dose /mouse while the group (B) was kept as control. Sera sample of both groups were .collected, two weeks later then subjected to sero-conversion using CFT, ELISA \& AGPT. Challenge was applied to the two groups by $45 \mu$ of living virus I/N $\left(10^{5}\right.$ TCID $_{50}$ $/ \mathrm{ml}$ ). Four mice from each group was sacrified at time intervals from $3^{\text {rd }}$ to $9^{\text {th }}$ days post challenge $(\mathrm{dpc})$ to detect the role of the vaccine in reduction of virus excretion

\section{Virus recovery :}

$10 \%$ of lung \& liver suspension of the sacrified mice from each group was prepared, inoculated on chorioallantoic membrane (CAM) of SPF-ECE 11-13 days, the inoculated eggs were incubated at $37^{\circ} \mathrm{C}$ for 5 days, examined for the presence of characteristic EHV pock lesion on CAM.

\section{2- In Horses :}

Four healthy susceptible horses with low antibodies titer ( $\leq 4$ neutralizing antibody) were divided into two groups. The first group was inoculated I/M with $2 \mathrm{ml} /$ horse of the prepared vaccine containing not less than $10^{7} \mathrm{TCID}_{50} /$ dose and the second group was kept as control. Sera sample were taken from each group after 21 days post vaccination (dPV) then monthly till $8 \mathrm{MPV}$ and subjected to serological tests (CFT \& SNT)

\section{Stability}

Random samples of the prepared vaccine were stored at different temperatures ( $4 \mathrm{C}^{\circ}$, room temperature $\left.\& 37^{\circ} \mathrm{C}\right)$ at intervals of time $(3,6$ months $\& 1,1.5,2$ year). 16 groups of mice (4mice/group) were inoculated with the prepared vaccine. 10 days later, sera samples were taken from each group and evaluated by ELISA to determine the vaccine stability.

\section{RESULTS AND DISCUSSION}

The great economic loss in horse breeding as result of EHV-1 infection resulted in perinatal death, abortion or respiratory manifestation in newly born foals. Thus, we must control this disease using vaccination. The present study is a trial for preparation and evaluation of inactivated EHV-1 oil (ISA-70) adjuvanted vaccine in both mice \&horses. 
Firstly, the locally isolated EHV.1 seed virus was propagated on VERO cells for further passages $3^{\text {rd }}, 4^{\text {th }}$ and $5^{\text {th }}$ passage with infectivity titer 7.0, 7.5, 8.0, \& $8.5 \log _{10}$ $\mathrm{TCID}_{50} / \mathrm{ml}$ respectively as shown in table (1) These titers are advisable recommended for preparation of inactivated vaccine (Mumford\&Bates,1984) where the vaccinal dose must contain not less than $7 \log _{10} \mathrm{TCID}_{50}$ (Mayr et.al., 1978).

Table (2) showed the complete virus inactivation which was carried out at two concentrations of BEI, $0.008 \mathrm{M}$ within 24 hours or $0.01 \mathrm{M}$ for 22 hours of incubation at $37^{\circ} \mathrm{C}$. As Bahnemann (1997) advised to use BEI in a low concentration as possible that produce complete virus inactivation so we use $0.008 \mathrm{M}$ in the vaccine preparation.

The residual virus infectivity proved that there is no residual virus through inoculated ECE, and two blind successive passages on VERO Cells.

Safety of the prepared vaccine was confirmed, there was no abortion in pregnant mice and mares, Also in mice there weren't roughed fur, loss of weight \& distress were observed (kirisawa et. al, 1995- OIE, 2008).

In table (3) showed the potency of the prepared vaccine of the inoculated mice, there was significant increase in the mean titers of ELISA and complement fixing antibodies (CF ab) was 1666 and 20 respectively. These results are in parallel with Kirisawa et.al, (1995) who stated that ELISA titer over 600 in sera sample of inoculated mice resist challenge .

Also, the duration of viral recovery was studied as shown in table (4), there was significantly shorter time in vaccinated mice than in control one The virus was recovered from the lungs of vaccinated mice $4 \mathrm{dpc}$ compared to $9 \mathrm{dpv}$ in the control one. This result coincidence with kirisawa et al., (1995) who stated that virus recovered from lungs of infected mice within 9 days.

On the other hand, immunogenicity of the vaccinated horses as shown in table (5) revealed that there was significant increase in CFab and neutralizing antibodies titer (N.ab) reaching the highest values at 1.5-3 MPV with mean CF ab \& N. ab titers $48 \&$ 24 respectively. Then decline gradually at 5-6 M. CF AB results agree with Singh et al.,(1992) who found that it may be detected for 110 days, Also Munford \& Bates (1984) revealed that CFab titer $1 / 10$ resist challenge and $N$. ab titer $\geq 25$ resistant to infection.

The stability of the prepared vaccine in table (6), clarify that the vaccine could be stored at $4{ }^{\circ} \mathrm{C}$ and withstand room temperature and $37^{\circ} \mathrm{C}$ for 2 years with good protective titer in the sera of inoculated mice. These results agree with taouji et al (1998). 
In conclusion, mineral oil ( Montanide ISA-70) induce good result(one dose) in both humeral immune response and cell mediated immunity as recorded by Taouji et.al. (1998). So, it's obvious that the prepared tissue culture inactivated oil (ISA- 70) adjuvanted vaccine is potent in either mice (laboratory good model for the vaccine evaluation) \& in horse (principle host)

\section{Acknowledgement}

It's pleasure to a great thank to Prof. Dr.., Soliman , I.M.A chief researcher of Equine viral disease vaccine dept.Abbasia, Cairo for his valuable scientific guide.

Table 1. Titration of EHV-1 at different passages

\begin{tabular}{|l|c|c|c|c|}
\hline No. of passages & P2 & P3 & P4 & P5 \\
\hline Virus titer & $7.0 *$ & 7.5 & 8.0 & 8.5 \\
\hline
\end{tabular}

* EHV-1 titer expressed as $\log _{10} \mathrm{TCID}_{50} / \mathrm{ml}$

Table 2. Inactivation of locally isolated EHV-1 using different concentrations of BEI at $37^{\circ} \mathrm{C}$

\begin{tabular}{|c|c|c|c|}
\hline \multirow{2}{*}{$\begin{array}{c}\text { Hours post } \\
\text { incubation }\end{array}$} & \multicolumn{2}{|c|}{$\begin{array}{c}\text { Virus titer with different BEI } \\
\text { concentration }\end{array}$} & $\begin{array}{c}\text { Control virus } \\
\text { (untreated) }\end{array}$ \\
\cline { 2 - 3 } & $0.008 \mathrm{M}$ & $0.01 \mathrm{M}$ & \\
\hline 0 & $8.5^{*}$ & 8.5 & 8.5 \\
\hline 12 & 5.5 & 5.0 & 8.3 \\
\hline 14 & 3.2 & 3.0 & 8.2 \\
\hline 18 & 2.4 & 2.0 & 8.0 \\
\hline 20 & 1.5 & 1.5 & 7.8 \\
\hline 22 & 1.0 & $-\mathrm{ve}$ & 7.8 \\
\hline 24 & $-\mathrm{ve}$ & $-\mathrm{ve}$ & 7.8 \\
\hline
\end{tabular}

* Virus titer expressed as $\log _{10}$ TCID $50 / \mathrm{ml}$

-ve : negative result 
Table 3. Immune response of mice inoculated with tissue culture inactivated oil adjuvanted EHV-1 vaccine by serological tests

\begin{tabular}{|c|c|c|c|c|}
\hline \multirow[b]{2}{*}{ Mice group } & \multirow[b]{2}{*}{ Mice No. } & \multicolumn{3}{|c|}{ Antibodies titer } \\
\hline & & ELISA & $\mathrm{CF}$ & AGPT \\
\hline \multirow{7}{*}{ A } & 1 & $1700 *$ & $16 *$ & + \\
\hline & 2 & 1690 & 8 & + \\
\hline & 3 & 1600 & 16 & - \\
\hline & 4 & 1550 & 32 & + \\
\hline & 5 & 1800 & 16 & - \\
\hline & 6 & 1660 & 32 & + \\
\hline & $\begin{array}{c}\text { M } \\
\text { ean }\end{array}$ & 1666.7 & 20 & - \\
\hline$B$ & Mean & - & - & - \\
\hline
\end{tabular}

$\left(^{*}\right)$ Reciprocal of highest dilution of serum

( - ) Negative result

Group A: Mice inoculated with the prepared vaccine

Group B: Control mice 
Table 4. Virus recovery of mice after challenge with EHV-1

\begin{tabular}{|c|c|c|c|}
\hline Animal group & Days post challenge & $\begin{array}{l}\text { No .of mice } \\
\text { recovered the virus } \\
\text { / total No. of } \\
\text { inoculated mice }\end{array}$ & $\begin{array}{l}\% \text { of } \\
\text { recovered virus }\end{array}$ \\
\hline \multirow[t]{5}{*}{ A } & 1 & $4 / 4$ & $0 \%$ \\
\hline & 2 & $3 / 4$ & $75 \%$ \\
\hline & 3 & $2 / 4$ & $50 \%$ \\
\hline & 4 & $0 / 4$ & $100 \%$ \\
\hline & 5 & $0 / 4$ & $100 \%$ \\
\hline \multirow[t]{9}{*}{ B } & 1 & $4 / 4$ & $0 \%$ \\
\hline & 2 & $4 / 4$ & $0 \%$ \\
\hline & 3 & $4 / 4$ & $0 \%$ \\
\hline & 4 & $4 / 4$ & $0 \%$ \\
\hline & 5 & $3 / 4$ & $75 \%$ \\
\hline & 6 & $3 / 4$ & $75 \%$ \\
\hline & 7 & $2 / 4$ & $50 \%$ \\
\hline & 8 & $1 / 4$ & $25 \%$ \\
\hline & 9 & $1 / 4$ & $25 \%$ \\
\hline
\end{tabular}


Table 5. Immune response of horses vaccinated with tissue culture (T.C) inactivated oil adjuvanted EHV-1vaccine by serological tests.

\begin{tabular}{|c|c|c|c|c|c|c|c|c|}
\hline \multirow[t]{2}{*}{$\begin{array}{l}\text { Time Post } \\
\text { vaccination }\end{array}$} & \multicolumn{2}{|c|}{ Horse 1} & \multicolumn{2}{|c|}{ Horse 2} & \multicolumn{2}{|c|}{$\begin{array}{l}\text { Mean EHV } \\
\text { antibody titer }\end{array}$} & \multicolumn{2}{|c|}{$\begin{array}{l}\text { Control mean } \\
\text { antibody titer }\end{array}$} \\
\hline & CFT & SNT & CFT & SNT & CFT & SNT & CFT & SNT \\
\hline Prevacc & $2^{*}$ & 4* & 2 & 2 & 2 & 3 & 4 & 2 \\
\hline $3 W P V * *$ & 16 & 8 & 8 & 4 & 12 & 6 & 4 & 2 \\
\hline 4WPV & 64 & 8 & 16 & 4 & 40 & 6 & 4 & 2 \\
\hline $1.5 \mathrm{MPV} * * *$ & 128 & 16 & 64 & 8 & 96 & 12 & 4 & 2 \\
\hline 2MPV & 164 & 32 & 32 & 16 & 48 & 24 & 4 & 2 \\
\hline 3MPV & 64 & 64 & 32 & 64 & 48 & 64 & 4 & 2 \\
\hline 4MPV & 32 & 64 & 16 & 32 & 24 & 48.5 & 4 & 2 \\
\hline $5 M P V$ & 16 & 32 & 8 & 16 & 12 & 24 & 4 & 2 \\
\hline 6MPV & 8 & 16 & 4 & 16 & 6 & 16 & 4 & 2 \\
\hline 7MPV & 4 & 8 & 2 & 8 & 3 & 8 & 4 & 2 \\
\hline 8MPV & 2 & 4 & 2 & 4 & 2 & 4 & 4 & 2 \\
\hline
\end{tabular}

* Reciprocal of serum dilution of CF \& SN antibodies.

** WPV: weeks post vaccination

*** MPV: months post vaccination 
Table 6. Stability of T.C inactivated oil adjuvant EHV-1 vaccine

\begin{tabular}{|c|c|c|c|}
\hline Storage Temp & $\begin{array}{l}\text { Group of } \\
\text { mice }\end{array}$ & Time of storage & $\begin{array}{l}\text { Mean ELISA } \\
\text { antibodytiter }\end{array}$ \\
\hline \multirow[t]{6}{*}{$4^{\circ} \mathrm{C}$} & 1 & Zero & 1700 \\
\hline & 2 & 3months & 1700 \\
\hline & 3 & 6 months & 1700 \\
\hline & 4 & 1year & 1700 \\
\hline & 5 & 1.5 year & 1700 \\
\hline & 6 & 2 year & 1700 \\
\hline \multirow[t]{5}{*}{ Room Temp. $\left(22-25^{\circ} \mathrm{c}\right)$} & 7 & 3 months & 1700 \\
\hline & 8 & 6 months & 1700 \\
\hline & 9 & 1 year & 1650 \\
\hline & 10 & 1.5 year & 1650 \\
\hline & 11 & 2year & 1690 \\
\hline \multirow[t]{5}{*}{ At $37^{\circ} \mathrm{C}$} & 12 & 3months & 1550 \\
\hline & 13 & 6 months & 1650 \\
\hline & 14 & 1year & 1500 \\
\hline & 15 & 1.5year & 1000 \\
\hline & 16 & 2 years & 800 \\
\hline
\end{tabular}


Fig (1) Inavtivation of locally isolated EHV-1

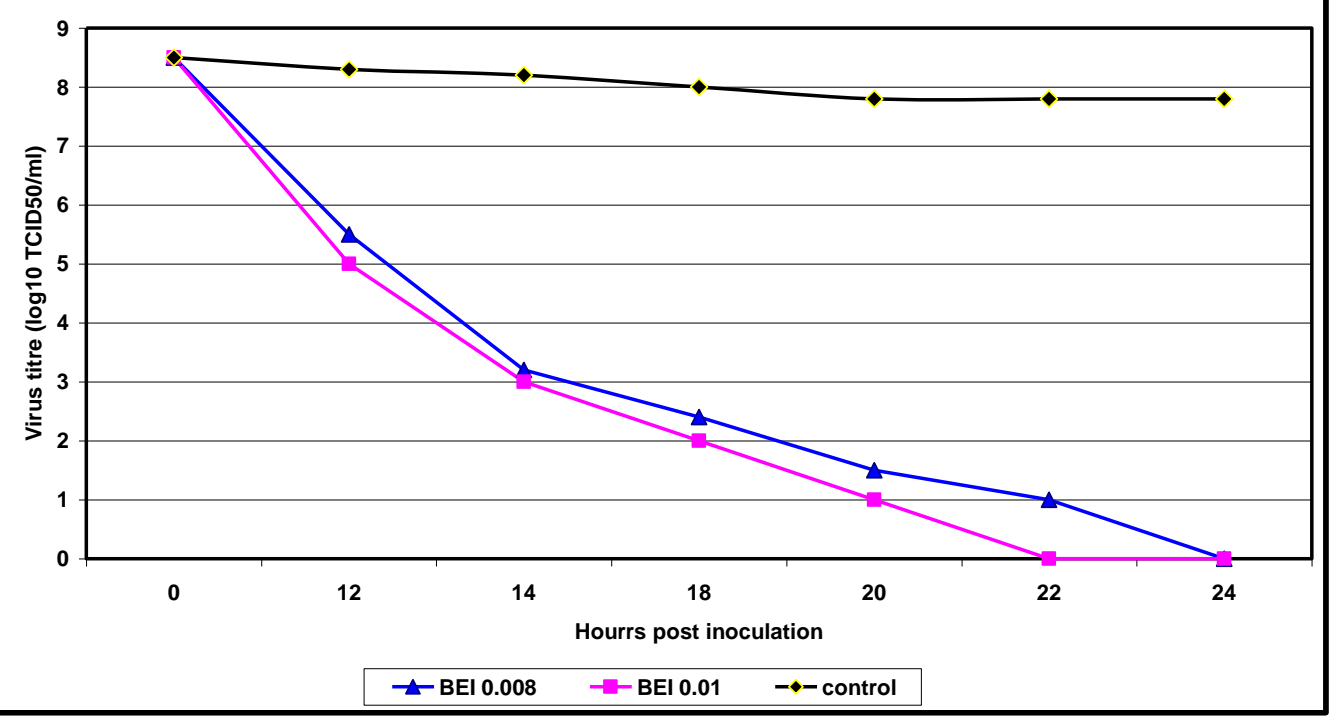

Fig (2)Immune response of horses vaccinated with T.C inactivated oil adjuvanted EHV-1 vaccine using CF\&SN tests

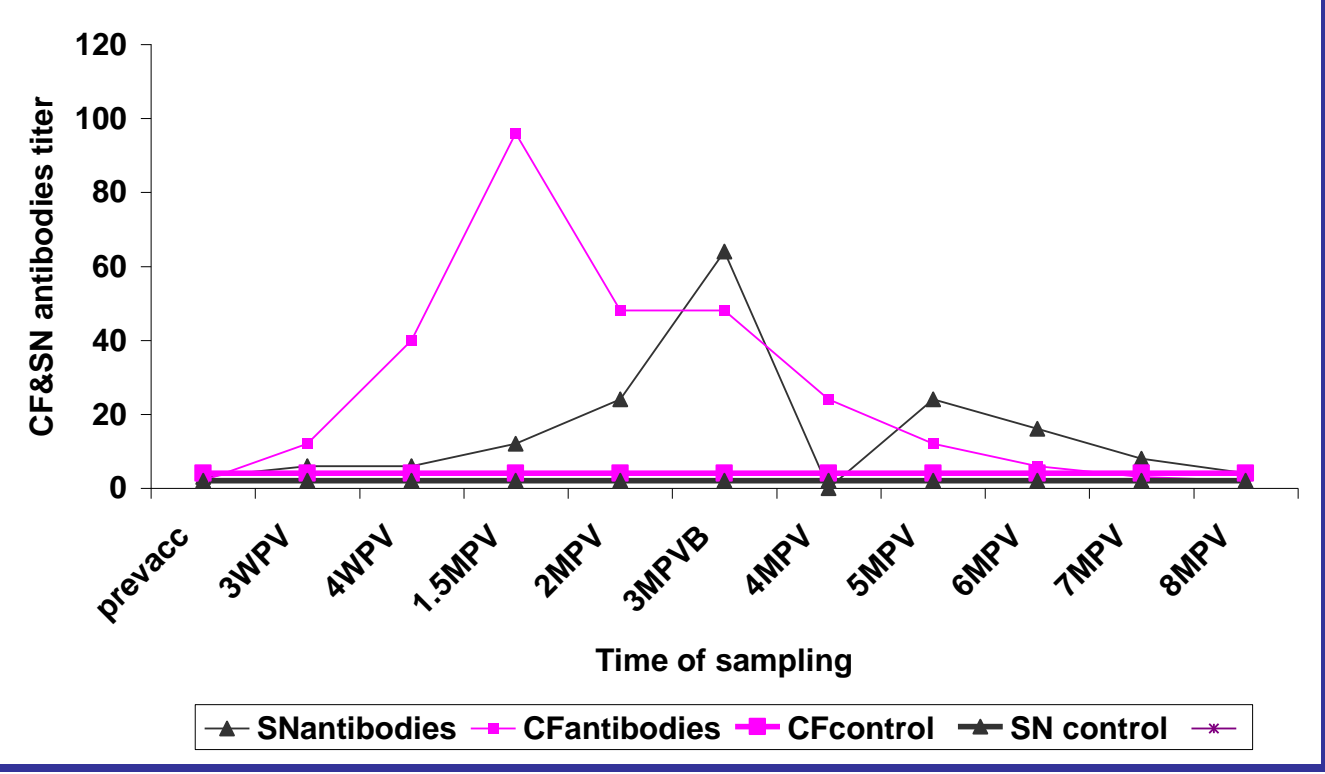

\section{REFERENCES}

1. Bahnemann, -H.G. 1997. Viral vaccine. Vaccine manual, the production \& quality control of veterinary for use in developing countries.

2. Bryans, J.T. 1978. Immunization of pregnant mare with an inactivated EHV-I vaccine. In Proc. 4th Int. Conf. Equine infectious disease.

3. Doll. E.R. and, J.T, Bryans. 1963. A planned infection program for immunizing mares against viral Rhinopneumonitis. Cornell Vet., 53: 249-262. 
4. -Hassanein, M.M. 1992. Preliminary findings for an inactivated African horse sickness vaccine using binary ethyleneimine. Rev.Elev.Med.Vet.Paystrop. 45(3-4):231-234

5. -Hassanein, M.M . , H. Maysa , F. El-Bagoury, A.K. Magda , M..M.A.El-Kabbany andM.A. Daoud. 2002. Trials for isolation and identification of equine herpesvirus abortion in Egypt.Vet. Med. J.,Giza, Vol. 50 No. (4: 977-986.

6. Kirisawa,R., M.Terada, N. Sekiya,.., Y.Kawakami and H. Iwai, 1995. Equine herpes virus in Encyclopedia of virology, 2nd ED., vol. (1) Academic press. pp. 508-Growth and potentials of attenuated strains of EHV-1 in lungs of mice. J.Vet. M.ed. Series b,42 (7) , 391-396

7. -Mayr.A.,P. Thein and Scheid. 1978. Immunization experiments with inactivated EHV-1. In proceeding $4^{\text {th }}$ Int. Conf., Equine infect. Dis., Lyon edited by Bryans, J.T. and Gerber Vet. Pub. Inc. Princeton, New Jercy, P.P 57-67 1975.

8. Mumford,J. A. and B.Bates. 1984.Trials of an inactivated EHV-1 vaccine : challenge with subtype (2) virus.Vet. Record (114) : 375-381.

9. Nehal, Saleh Abdel Rahman. 2006. Preliminary trials for production of equine viral abortion inactivated vaccine. Ph. D. Thesis, virology, Benha Univ.

10. OIE. 2008 . Equine rhinopneumonities. Manual of standards diagnostic tests \& vaccines $5^{\text {th }}$ edition chapter 2-2-9 pp 893-903

11. Patel, J.R., A. Bateman, J.Williams andS. Didlick. 2003. perivation and characterization of alive equine herpesvirus-1 (EHV-1) vaccine to protect against abortion \& respiratory disease due to EHV-1. Vet., Microbiol., 91 (1) : 23-30.

12. Reed, L.Tand H. Munech. 1938. A simple method of estimating $50 \%$ end points Am., J. Hyg., 27: 493.

13. Shinner, G.R.B. and J. Davies. 2000. Efficacy of inactivated vaccine for equine herpesvirus-1 in novel hamster model. Intervirology, 43 (1) : 27-35.

14. Singh, B.K., M.P.Yadav and P.K.Uppal. 1992. Sero-epidemiology of EHV-1 infection in Indian horses. Int. J. Anim Sci., 7 (1) : 43-46.

15. Taouji S., I. Nomura, S. Giguere , S.Tomomitsu, T. Kakuda, V. Ganne, and S.Takai. 2004. Immunogenicity of synthetic peptides representing linear B-cell epitopes of VapA of Rhodococcus equi. Vaccine, 22 : 1114-1123.

16. -Thomson, G.R, J.A. Munford and W., Powright. 1978. Immunological response of conventional \&gnotobiotic foal to infection \&inactivated antigens of EHV-1.Equine infectious Dis.,4th ed.,edited by Bryans,J.T\&Gerber,H. Vet. Pupliication Inc,Princeton ,NJ :83-92

17. Yoland, Bishop. 2001. Immunological preparation for horses. Vet. Formulary, fifth ed., pp. 58 


\section{الاستجابة المناعية للخيول المحصنة بلقاح الإجهاض المعدي المثبط والمحفز مناعياً باستخدام مونتانيا}

\section{SA-70}

صفاء عبد المنعم على وردة جمال الاين محمد حسين

معرل بحوث وإنتاج الأمصال واللقاحات البيطرية -العباسية-/لقاهرة

تم بنجاح تحضير لقاح نسيجي زيتي مثبط لمرض الإجهاض المعدي الفيروسي في الخيول

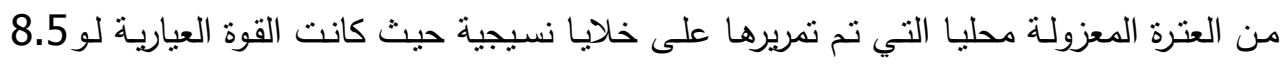

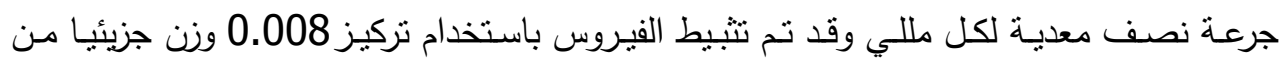

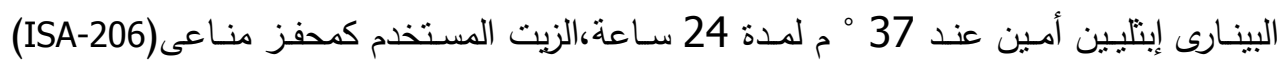

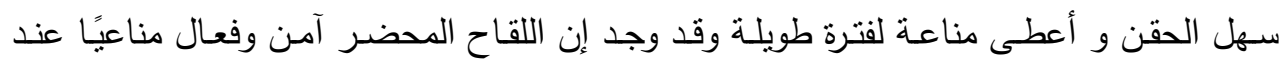

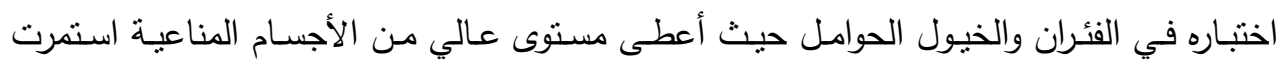

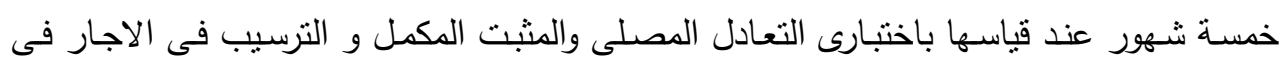

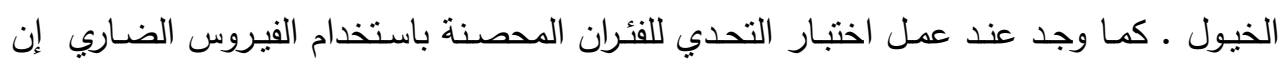

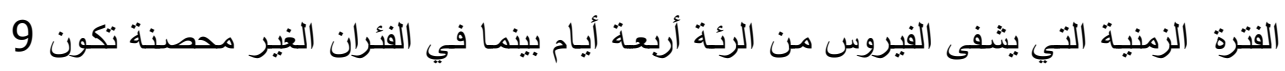
أيام. يحفظ اللقاح عند 40م و يتحمل درجة حرارة الغرفة ،37م لددة سنتين محتفظا بكامل كفاءته المناعية 